\title{
The future of archaeology in Africa
}

\author{
Innocent Pikirayi*
}

${ }^{*}$ Department of Anthropology and Archaeology, University of Pretoria, Hatfield 0028, South Africa (Email: innocent.pikirayi@up.ac.za)

\section{Introduction}

The $14^{\text {th }}$ Congress of the Pan African Archaeological Association for Prehistory and Related Studies, and the $22^{\text {nd }}$ Biennial Meeting of the Society of Africanist Archaeologists were hosted by the University of the Witwatersrand, Johannesburg, South Africa from the 14-18 of July 2014. Keynote speakers offered insights into the state of archaeology as a discipline in Africa; they acknowledged its diverse and wide-ranging scope, and the achievement of scientific advances in investigating the African past, but they also noted a number of challenges confronting the discipline. These included persistent barriers to the investigation of the past. For example, Africa's past continues to be interpreted in exotic terms, following Anglo-American academic traditions. By this, I mean that the archaeology syllabus and research agenda in Africa still follows the model set by British, North American and, to some extent, mainland European universities. The academic curriculum remains weak in terms of decolonising the discipline, and it is largely unable to challenge the dominant theoretical and even philosophical positions, which have prevailed since the rapid development of archaeology as a discipline in the twentieth century. Poverty among African societies and the largely poor African economies provides an uncomfortable setting within which archaeology is practised; this naturally raises questions about how much financial priority should be afforded to investigating the past. Coupled with this are the serious, and escalating, political and security challenges afflicting the continent. These barriers need to be broken down; a continent-wide approach is required to achieve this end.

In evaluating current theoretical and practical approaches to archaeology in Africa and in attempting to predict the future direction of the discipline, it is important to acknowledge the numerous interpretive frameworks that archaeologists use to understand the archaeological record of the continent and, by extension, the broad-based disciplinary identities that archaeology has adopted and evolved. Attempts to move towards interdisciplinary research and communication beyond archaeology purely as a science, and the subsequent influence 
of archaeological practices on other disciplines are, in my view, the reason processual and post-processual approaches dominated archaeological thinking from the 1970s to 2000. Chadwick (1998) saw archaeology drifting towards 'the edge of chaos', with a considerable schism opening up between research- and development-led approaches, coupled with imperatives to develop more reflexive, recursive methodologies (see Hodder 1997). Kristiansen (2009) saw developments post-1985 as characterised by much greater diversity. This essentially was in reaction to the dominance of the Anglo-American tradition and, to a limited extent, to mainland European and Classical traditions of investigating the past of societies beyond these continents. Perceived by some as the new post-processualism (Preece 2010), it was neither 'chaos' as Chadwick (1998) puts it, nor an exercise in deconstruction (Roberts 2010). Rather, it was a signal that the practice of archaeology had changed and that the interpretive frameworks accompanying it were unsustainable.

I argue first that universalising approaches to archaeology in Africa are bound to fail. Second, the diversification of archaeological theory post-1990 demanded that theory in African archaeology be informed by locally-based epistemologies and worldviews. Third, as African archaeology is about the writing of the past of Africa, scholars must attach importance to memory because it is an integral part of African history-making. Finally, while acknowledging the divide between heritage management and mainstream academic archaeology, the latter must communicate relevance to non-professionals to ensure its survival as a discipline.

\section{'African archaeology' or 'archaeology in Africa'?}

One of the criticisms levelled at new archaeology is that it attempts to universalise. New approaches in contemporary archaeology question this universalism by seeking comparative generalisations that explore the diversity of local contexts. Universalising approaches have always failed. This can be illustrated by reference to two prominent publications: Edward Hallet Carr's What is history? (1961) and Anthony Grafton's What was history? The art of history in Early Modern Europe (2007). Carr's concern is how to write history in the twentieth century, while Grafton targets the period 1550-1700 and how to read the history of that time. Grafton focuses on the development of ars historica, the genre of humanist historiography that arose during the later Renaissance out of earlier criticism by the humanists, to achieve its new universalising form in the sixteenth century. He considers its religious, political, philosophical, scientific and professional applications and its demise in the early eighteenth century. Grafton argues that earlier scholarship on historical criticism had defined ars historica too narrowly. The demise of ars historica by the mid-eighteenth century was the consequence of numerous internal weaknesses and shifting interests and criteria; its scope had generated an unsustainable information overload, and consequently lost focus and relevance.

Ars historica attests to early but ultimately unsuccessful attempts towards 'globalising' the writing of history. Resonances with archaeology become apparent in the work of Francois Baudouin (1520-1573), who advocated the study of art, coins, inscriptions, travellers' reports and other para-historical texts, and the inclusion of the histories of ancient and contemporary civilisations. A lot has changed since then in the writing and reading of history, and this is also true for archaeology. The practice of archaeology in Africa has further changed 
since the 1990s, so that we no longer talk about 'African archaeology' but 'archaeology in Africa'. By the latter, we understand a universalised, globalised discipline, no longer driven by local context (see Mizoguchi 2015: 13-15). Universalising archaeology, however, imposed barriers on the practice of archaeology in Africa, with researchers readily adopting approaches and epistemologies from European and American academic institutions, at the expense of those based in Africa. This created very confused, uneven and multiple theoretical landscapes, few of which were relevant to the African context. It is unsurprising that when most African states attained political independence from the late 1950s onwards, they adopted Western education as a basis for aligning their economies and infrastructure with those of the more developed north. The obvious outcome was a neo-colonialism, perpetuating dependency on Europe and the continued adoption of a Western system of values.

\section{Rethinking theory}

Theoretical discussions in Africa since the early 1990s have focused on the role of archaeological theory. Questions have included whether theory was relevant to archaeology in Africa and, if so, what direction it would take (see Shaw 1989; Musonda 1990; Ellison et al. 1996; Hassan 1999). While common sense alone is not enough to interpret archaeological practice, theory allows us to explain it, but whose theory are we using (see Johnson 2010)? Mizoguchi (2015) notes that one of the consequences of globalisation is the creation of a global academic terrain characterised by producers and consumers of theory, with African and Latin American nations falling into the latter group. These, he says, are further characterised by different ways of practising archaeology and by different purposes and objectives in those practices. I suggest that there is a need to situate local epistemologies and approaches at the centre of our theorising to make sense of Africa's past. It is only in this way that archaeology can make sense of African material culture. In doing so, I go beyond Mizoguchi's (2015: 17-18) acknowledgement of the post-processual contribution to archaeological thinking outside Europe and the USA, by calling for researchers working in the African continent to create their own theories.

Leading scholars in archaeological theory have asked where archaeological theory is going and what shape it will take in the future (Hodder 2012). For the African continent we specifically need to ask how archaeological theory interacts with changes in practice and political and social circumstances. Who should drive the change and what intellectual traditions are likely to emerge? New approaches, with labels such as processualism, postprocessualism, cognitive archaeology, Darwinian archaeology, agency, gender, social complexity, heritage studies and so on, underline dissatisfaction with previous approaches and their social construction.

European archaeology, for example, is firmly rooted in modernity, and the philosophical ideas developed in the previous formative centuries of the discipline (Thomas 2004). Thomas suggested that we should no longer borrow interpretive approaches that are grounded in modernity to understand what is different from our own. The language of the past and, by extension, the construction of knowledge of Africa's past should instead use archaeology to tell the story of the past of Africa (see Joyce 2002). Funari (2009) observed that the language and the accessibility of publications in archaeology are fundamental. In that context, what could archaeologists in Africa do to address the language and access needs of the public? 
Can archaeology promote and facilitate translation and encourage academic departments to expand training and persuade students to develop their language skills? Individuals and professional organisations are making efforts to support global scholarship and exchange. The World Archaeological Congress (WAC) has been particularly active in this regard. When I speak of translation I do not simply mean the production of archaeological texts in local vernaculars, but also reproducing the same texts in formats that are accessible to students and the public. The technical terminology of archaeology must be translated into a language that the public can understand and easily relate to (see also Mizoguchi 2015: 20).

Archaeological research in Africa is no longer simply an exercise in knowledge production. It is also about the negotiation of such knowledge with local and indigenous communities. Although critical in setting new directions in archaeology, such a dialogue has been missing in archaeological practice in Africa. This should not spell the end of archaeological theory, as some have suggested, but will change its course (Johnson 2009). The processual vs postprocessual paradigms should not be maintained and used to explain the African past, as they are part of a system of knowledge production that is irrelevant to the African context. Explaining and interpreting the past of Africa should be done differently.

It is certainly the case that, across large areas of archaeological interpretation and in very different parts of the globe, theory has mattered. That is, between 1960 and 2000 what archaeologists actually did changed radically, and it changed for the reasons that cannot be explained solely in terms of the changing practicalities of the discipline. It is not unreasonable, therefore, to conclude that theory will continue to matter in the present and that careful and explicit theoretical reflection will continue to be a central feature of the discipline (Johnson 2009: 85).

Bridging the gap between the archaeological paradigms mainly followed in Europe, and those practised elsewhere, defines the future of the discipline (Jones 2009). According to Jones (2009), such theory must be negotiated and shifts in knowledge production must take into account for the other: local and descendant communities and indigenous knowledge systems. Ultimately, fresh knowledge about the past is required—by positioning debate and negotiation in a spatial and material context. In a session at the 2008 World Archaeological Congress, John Carman and Carol McDavid proposed that the future of archaeology, including theory, lies in archaeological heritage and public archaeology, where archaeologists have to confront the central issues of what archaeology does, what it makes and what it is for. For Africa, archaeology has to decolonise completely by disentangling itself from the philosophical ideas grounded in European modernity. While it must also continue to use advances in science to unlock the secrets of the African past, theoretical trajectories must be informed by local African contexts.

\section{Decolonising archaeological practice}

According to Fontein (2006: 131):

historical and archaeological discourses are Eurocentric, in the sense that they are based upon perceptions of the past and time that originated as a result of the European enlightenment, which arrived in Africa on the back of colonialism.

Archaeology has colonial origins, and it is this colonial burden that archaeologists seek to rid themselves of, by identifying other characteristics that may be associated with a postcAntiquity Publications Ltd, 2015 
modern discipline. In recent years, critiques of archaeological practice have set new agendas for it that are politically aware of, sensitive to and harmonious with the goals of descendant communities. There are practical implications of archaeological research for the descendant communities on whom it focuses. For example, presenting archaeology essentially as a science negates descendants' rights to their own perspectives and understandings of the past and its use in the present. Archaeology needs to focus more on local knowledge in collaboration with local communities. Such an approach challenges conventional archaeological theories and practices, since it assumes that Western scientific approaches to archaeological theory and method are not necessarily the 'best' way of interpreting the past. Who benefits from the results of archaeological research begs the question of how archaeological knowledge is disseminated and shared between practitioners and those communities who constitute the subject of study. By failing to share and communicate such knowledge, archaeologists have been in control of the pasts of others, and this is no longer acceptable.

Yet is there truly a 'post-colonial' archaeology in Africa? In sub-Saharan Africa archaeologists are challenged to demonstrate the capacity of their discipline to engage local and descendant communities (Schmidt 2009). This involves networking and going beyond the 'working together' approach, towards genuine and equal collaboration between archaeologists and communities. The general public has also become very sceptical about the role of archaeology in its representation of the past of communities it seeks to study. In subSaharan Africa participatory public archaeology remains a relatively new approach (Thiaw 2003; Schmidt \& Pikirayi 2014). Archaeological research is confronted with internecine warfare, religious battles, terrorism and other conflicts. Resistance by the general public and local communities is a strong factor, as they associate archaeology with theft and destruction of cultural material, and the desecration of cultural heritage including sacred places. Local communities and the public are also increasingly sceptical about the knowledge claims of a discipline that is framed within a Western system of values and whose relevance is not apparent. It is therefore evident that archaeologists are not yet fully post-colonial in their approaches, with colonial traditions persisting in many parts of the continent. Pag'an-Jim 'enez (2004), for example, stresses the importance of situating the multiple archaeological practices of Latin America in their particular contexts, in reaction to the so-called 'globalised' and 'post-colonial' archaeologies. She argues that the different processes that give rise to the many ways of practising archaeology around the world are embedded in multiple and divergent dynamics of socio-cultural and political interactions. Instead of depending on interpretation from the usual theory-production centres, she suggests that archaeologists open new, dialectical and parallel channels of communication to articulate more balanced characterisations of the world's archaeologies. Analysing multiple archaeological practices in their own contexts allows for more coherent flows and linkages of information between praxis and theories inherent in particular socio-political contexts.

The main crisis in African archaeology is the perception among its practitioners that it is just a 'science' of investigating the past, with no bearing on the present. A good example is Stone Age archaeology, where, although considerable research is in progress, the discipline remains largely unaffected by contemporary politics, giving its practitioners a comfort zone and a sense of moral or ethical victory over Iron Age archaeologists, who have to confront the current political environment (see Tomaskova 2003: 484). Publications in 
scientific journals alone are not sufficient; they need to be complemented by other methods to convey the results and relevance of archaeology to a wider public. Archaeology has also failed to confront social ills such as racism and critical issues of equity, especially in South Africa, where despite efforts towards adopting a transformative agenda there is considerable resistance by archaeologists.

Lynn Meskell (2007) brings archaeological and ethnographic evidence to bear on a holistic understanding of South Africa's self-identification by developing its protected areas and cultural heritage sites. Her case study of Kruger National Park vividly demonstrates this process through both cultural and natural resource development. She argues that cultural heritage has emerged as secondary to the conservation of nature, but that the idea of heritage as therapy provides a valuable, on-going strategy for socio-economic empowerment and development. She used the term 'archaeologies of failure' (Meskell 2007) to imply that South African archaeology has lost relevance. The fundamental question is whether we should continue to dig small trenches in the ground under the guise of scientific research, assuming communities do not matter. In another publication, Meskell (2011) was evidently frustrated by the lack of meaningful change in South African archaeology, and noted that "archaeology has still a long way to go, and new generations with new visions are sorely needed" (Meskell 2011: 155). How then do we make archaeology relevant to present day circumstances? How do we justify its existence in the academic departments where it is taught and practised? What role should it play in the knowledge society? According to Fritz and Plog (1970: 412), unless archaeologists find ways to make their research increasingly relevant to the modern world, the world will find itself increasingly capable of getting along without archaeologists.

\section{History and memory}

One approach that African archaeology should take involves the use of history and memory (Schmidt 1995a \& b, 2006). This allows for a more informed understanding of European colonialism on the African continent, as well as African history-making. As an historical archaeologist since the late 1980s, focusing mainly on southern Africa, I have been concerned by the failure to construct a coherent body of theory that properly or adequately explained my data (e.g. theorising African-European contact and understanding subsequent identities). One of the problems was the failure to engage with both colonial and local narratives, as an exercise in source criticism and as an approach in formulating alternative histories and archaeologies of societies.

African societies have complex histories of migration and settlement, intertwined with memory, history and landscape. The documentation, provenancing and mapping of 'cultures of orality' demand approaches that are particular to the continent. African history is imagined differently in African contexts, and this should influence how we conduct our research and write about the past. Memory is part of African history, part of the African historical experience and landscape, and is African history-making. The written word is inseparable from the spoken one. Although both are valid sources, oral texts provide a more authoritative context and are a medium valued by those who preserve them. We have afforded printed texts a privileged position at the expense of the oral and this has 
shaped history-writing and the production of certain historical pasts. How we deal with inherent biases in the production of narratives on the African past is something Schmidt and Patterson (1995) define as how archaeology should be undertaken in non-Western contexts.

Invoking memory in African history-making is also about how African indigenous knowledge systems affect and transform their pasts. It is about recognising that knowledge is a universal resource because of its varied and diverse forms, which needs to be preserved. One must be aware, however, that Western knowledge, although valuable, has opportunity costs, while local knowledge systems are multifaceted and far more complex. By opportunity costs I mean that Western knowledge was and still is being used to undermine other knowledge systems. Thus, there should not be a single, monolithic and dominant narrative of and about the past. There cannot be a single, monolithic and dominant narrative of and about the past in Africa. The issue, rather, is the survival of local communities and African knowledge systems that have been judged irrelevant by Western scholarship. The emancipatory value of indigenous knowledge systems is that that they oblige us to contextualise this dichotomy between the inscribed word and the spoken word in history and archaeology in Africa. The issues resonate beyond Africa, where we see different historical archaeologies aimed at issues local and global, and the intricate and transformative connections between them. How do we use material culture to understand subaltern agency, cultural appropriation and colonial entanglement? What does European material culture found in local sites represent, and how should we read the materiality of colonial encounters? These key questions are also relevant to understanding history-making in Africa. The objective is to find approaches to archaeology that seek to inform the past in markedly different ways from those used outside the African continent.

Attempts to re-interpret the past of Africa within the framework of indigenous knowledge systems and epistemologies or philosophies continue to be shunned in much of Africa, and South Africa specifically, as their critics view these as 'unscientific'. This represents a failure to realise that African archaeology needs to decolonise itself completely and that one of the most important ways in which it can achieve this is by rejecting the philosophical inheritance of Western modernity, and in particular that value set of the Enlightenment. There is a rich and complex series of traditions of African philosophy that could be drawn on in this project (e.g. Coetzee \& Roux 2003; B r o w n 2004; Wiredu 2005). While they are often grounded in traditional systems of thought, they are also framed in ways that explicitly challenge the assumptions of the Western philosophical tradition.

\section{The future of archaeology in Africa}

Archaeology has a future and is relevant, and it can play a useful role in critical issues facing the world today (Davis 1989). According to Sabloff (2008: 17), archaeological research can inform us in general about lessons to be learned from the successes and failures of past cultures, and provide policy makers with useful contexts for future decision-making; it can also make an immediate difference in the world today and directly affect the lives of people at this very moment. 
Although archaeologists can 'predict the past' and construct models to help these predictions, they are wary of predicting the future (Davis 1989). The challenges for Africa and the practice of archaeology in Africa remain immense, given a rapidly changing globalknowledge economy and socio-economic and political landscape (see Musonda 1990: 9 ). These challenges can be confronted by a dissemination of archaeological knowledge that allows for effective communication of the discipline to both non-archaeologists and nonexperts, including the public. The practice of archaeology in Africa has failed communities within which archaeologists work, and confronting this failure has not been easy.

Researchers from different parts of the world are discussing how archaeology may be of use to contemporary society, ranging from issues to do with peace, justice and the environment (Little 2009), through societal collapse and resilience (Costanza et al. 2007) to urban planning (Smith 2007, 2010; Sinclair 2010). This implies that some particular archaeological findings are relevant to present day concerns (see Stump 2013), but communicating such findings remains problematic (see Beavis \& Hunt 1999).

The future of archaeology in Africa and the theoretical and methodological terrain in which it will be framed depend heavily on contemporary developments affecting the continent, such as infrastructure and economic development, environmental degradation, poverty alleviation, growing social inequalities and the resultant social tensions, and terrorism. The continent is already witnessing massive infrastructural expansion triggered by oil and natural gas exploitation, huge investment in information and communications technologies, and rapid urbanisation as it attempts to respond to globalisation. Negatively impacting on these trends is political instability, mainly in the form of terrorism, religious and ethnic tension, continuing legacies such as racism and social inequality, increased famine and environmental disasters in the wake of climate change. All of these have a bearing on the way Africans view their pasts and perceive their futures or destinies. Archaeology will only make a meaningful impact on both academic and public or community contexts if it addresses issues of relevance, particularly those resonating with these experiences (see Rockman \& Flatman 2002; Costanza et al. 2007; S m it h 2007, 2010; Little 2009; Sinclair 2010).

Applying archaeological knowledge for a better appreciation of the present and the future not only requires a shift from perceiving the discipline as purely 'scientific' in approach, it must be viewed instead as the science of the humanities and social sciences, giving a deeper appreciation of humanity's long-term history. This requires detailed engagement with local and indigenous communities and the public in appreciating the value of the past in the present. Investment in mobile phone technologies-the current trend in Africa-for example, could be channelled towards conveying heritage information, disseminating critical knowledge of its value to the African past and present, and how this heritage may be conserved. This will help offset the negative impacts of infrastructural development that indeed have the potential to erase the continent's past completely. Thus, development-driven archaeology will increasingly dominate Africa within the next decade or so, and the divide between heritage management and academic archaeology will be narrowed. A further driving factor will be the rapidly changing landscape of higher education.

In the medium to long term, by around 2030, archaeology in Africa will have been transformed, not only through the need to redefine its role in a post-colonial context, 
but also to show how the discipline may provide answers to pressing problems in society such as poverty and the adverse impacts of climate change. Archaeologists will no longer have the luxury to dig small holes and trenches under the guise of scientific research and pretend that communities have nothing to do with such activity. There will be an expansion of the discipline's professional base, making it more accessible to the public and to communities, some of whom are closely associated with the heritage and sites that archaeologists investigate. Faced with the development challenges mentioned, archaeology will increasingly be dominated by development-led approaches, upon which universities and research in museums will have to rely.

Development-led approaches will provide the basis for sharing knowledge among archaeologists as well as the public. They will also call for properly resourced archaeological archives as an exercise in the management of heritage collections. To understand better the context from which the archaeological heritage is derived, archaeological and historic landscape characterisation will also be necessary, framed within local knowledge systems. This will provide the basis for public awareness, understanding and appreciation of the value of the past.

All of this requires an evaluation or foresight study to assemble initial information that will enable archaeologists in Africa to be part of the process of change. One factor is the rapidly changing higher education environment in Africa and the rest of the world. Higher education provides the skills base needed to develop the continent, and as such archaeology is expected to make a meaningful contribution to development; otherwise archaeology departments at both universities and museums will be threatened with closure. In countries such as South Africa, the skewed racial demographics, where archaeology continues to be dominated by a minority of white archaeologists, coupled with a very slow pace of change, particularly in the training of black and indigenous archaeologists, constitutes a serious threat to the discipline. These threats or barriers are neo-colonial in character, and will only be removed through legislation and continuous curriculum changes. These imperatives demand that archaeology and the ideas around it be undertaken differently, if the discipline is not to risk becoming completely irrelevant by 2030 .

\section{Acknowledgements}

This paper is a result of collaboration and discussions with Paul Sinclair, Peter Schmidt, Munyaradzi Manyanga, Shadreck Chirikure and Ndukuyakhe Ndlovu. I would like to thank all of them for their critical approach to archaeological theory, and its relevance both now and in the future of archaeological practice in the African continent. Chris Scarre invited me to contribute to the discussion of the future of archaeology, and his constructive comments to earlier drafts of this paper are hereby acknowledged.

\section{References}

BEaVIS, J. \& A. HunT.1999. Communicating archaeology. Papers presented to Bill Putnam at a conference held at Bournemouth University, September 1995. Bournemouth \& Oxford: Bournemouth University School of Conservation Sciences \& Oxbow Books.
BROWN, L. 2004. African philosophy: new and traditional perspectives. Oxford: Oxford University Press. http://dx.doi.org/10.1093/019511440X.001.0001

CARR, E.H. 1961. What is history? London: Macmillan. 
CHADWICK, A.M. 1998. Archaeology at the edge of chaos: further towards a reflexive excavation methodology. Assemblage 3. Available at: http://www.assemblage.group.shef.ac.uk/3/3chad. htm\#l (accessed 10 March 2015).

Coetzee, P. \& A. Roux. 2003. The African philosophy reader. London: Routledge.

Costanza, R., L. Graumlich \& W. STEFFEN (ed.) 2007. Sustainability or collapse? An integrated history and future of people on earth. Cambridge (MA): MIT Press.

DAVIS, H.A. 1989. The future of archaeology: dreamtime, crystal balls. American Journal of Archaeology 93: 451-58.

http://dx.doi.org/10.2307/505595

Ellison, J., P. RobertshaW, D. Gifford-GonZalez, R.J. McIntosh, A.B. Stahl, C.R. Decorse, L.H. Robbins, S. Kent, A. Ngaba-Waye, M. SAHnouni \& A.K. Segobye. 1996. The African Archaeological Review 13: 5-34. http://dx.doi.org/10.1007/BF01956131

FONTEIN, J. 2006. The silence of Great Zimbabwe: contested landscapes and the power of heritage. London: UCL Press.

FriTZ, J.M. \& F. PLOG. 1970. The nature of archaeological explanation. American Antiquity 35: 405-12. http://dx.doi.org/10.2307/278113

FUNARI, P.P. 2009. Historical archaeology and global justice. Historical Archaeology 3(4): 120-21.

Grafton, A. 2007. What was history? The art of history in Early Modern Europe. Cambridge: Cambridge University Press.

HaSSAN, F.A. 1999. African archaeology: the call of the future. African Affairs 98: 393-406. http://dx.doi.org/10.1093/oxfordjournals.afraf. a008046

HODDER, I. 1997. Always momentary, fluid and flexible: towards a reflexive excavation methodology. Antiquity 71: 691-700.

HodDER, I. (ed.) 2012. Archaeological theory today. Cambridge \& Malden (MA): Polity.

JoHnson, M.H. 2009. The theoretical scene, 1960-2000, in B. Cunliffe, C. Gosden \& R.A. Joyce (ed.) The Oxford handbook of archaeology: 71-88. Oxford: Oxford University Press.

- 2010. Archaeological theory: an introduction. Malden (MA) \& Oxford: Blackwell.

Jones, A. 2009. Into the future, in B. Cunliffe, C. Gosden \& R.A. Joyce (ed.) The Oxford handbook of archaeology: 89-114. Oxford: Oxford University Press.

JOYCE, R. 2002. The languages of archaeology. Oxford: Backwell. http://dx.doi.org/10.1002/ 9780470693520
KRISTIANSEN, K. 2009. The discipline of archaeology, in B. Cunliffe, C. Gosden \& R.A. Joyce (ed.) The Oxford handbook of archaeology: 3-46. Oxford: Oxford University Press.

- 2011. Theory does not die, it changes direction, in J. Bintliff \& M. Pearce (ed.) Death of archaeological theory?: 72-79. Oxford: Oxbow Books.

LITTLE, B.J. 2009. What can archaeology do for justice, peace, community, and the earth? Historical Archaeology 43(4): 115-19.

MeSKELL, L. 2007. Falling walling and mending fences: archaeological ethnography in the Limpopo. Journal of Social Archaeology 33: 383-400.

- 2011. The nature of culture in the new South Africa. Oxford: Wiley-Blackwell.

MizoguCHI, K. 2015. A future of archaeology. Antiquity 89: 12-22. http://dx.doi.org/10.15184/aqy.2014.39

MusONDA, F.B. 1990. African archaeology: looking forward. African Archaeological Review 8: 3-22. http://dx.doi.org/10.1007/BF01116870

PAGÁN-JiméneZ, J.R. 2004. Is all archaeology at present a post-colonial one? Constructive answers from an eccentric point of view. Journal of Social Archaeology 4: 200-13. http://dx.doi.org/10.1177/ 1469605304041075

PreECE, J. 2010. Post-holier than thou: analogical theory and me. The Post Hole 13: 14-17.

Roberts, D. 2010. A reply to Preece-hole-istic post-processualim? The Post Hole 14: 21-24.

Rockman, M. \& J. Flatman. 2002. Archaeology in society: its relevance in the modern world. New York: Springer.

SABLOFF, J.A. 2008. Archaeology matters: action archaeology in the modern world. Walnut Creek (CA): Left Coast.

SCHMIDT, P. 1995a. Using archaeology to remake African history, in P. Schmidt \& T. Patterson (ed.) Making alternative histories: the practice of archaeology and history in non-Western settings: 118-47. Santa Fe (NM): School of American Research.

- 1995b. Introduction. From constructing to making alternative histories, in P. Schmidt \& T. Patterson (ed.) Making alternative histories: the practice of archaeology and history in non-Western settings: 1-24. Santa Fe (NM): School of American Research.

SCHMIDT, P. (ed.) 2006. Historical archaeology in Africa: representation, social memory, and oral traditions. Walnut Creek (CA): AltaMira.

- 2009. Postcolonial archaeologies in Africa. Santa Fe (NM): School for Advanced Research Press. 
SCHMIDT, P. \& T.C. PATTERSON (ed.) 1995. Making alternative histories: the practice of archaeology and history in non-Western settings. Santa Fe (NM): School of American Research.

SCHMIDT, P. \& I. PIKIRAYI. 2014. Final schedule for Wenner-Gren. Workshop on community archaeology and heritage in Africa, March 24-28 2014. Gainesville: University of Florida, the Wenner-Gren Foundation for Anthropological Research.

SHAW, T. 1989. African archaeology: looking back and looking forward. The African Archaeological Review 7: 3-31. http://dx.doi.org/10.1007/BF01116836

SINCLAIR, P.J.J. 2010. Towards an archaeology of the future: the urban mind, energy regimes and long-term settlement system dynamics on the Zimbabwe Plateau, in P.J.J. Sinclair, N. Gullög, F. Herschend \& C. Isendahl (ed.) The urban mind: cultural and environmental dynamics: 591-616. Uppsala: African and Comparative Archaeology, Department of Archaeology and Ancient History, Uppsala University.

SMITH, M.E. 2007. Form and meaning in the earliest cities: a new approach to ancient urban planning. Journal of Planning History 6: 3-47. http://dx.doi.org/10.1177/1538513206293713
- 2010. Sprawl, squatters, and sustainable cities: can archaeological data shed light on modern urban issues? Cambridge Archaeological Journal 20: 229-53. http://dx.doi.org/10.1017/ S0959774310000259

STUMP, D. 2013. On applied archaeology, indigenous knowledge, and the usable past. Current Anthropology 54: 268-98. http://dx.doi.org/10.1086/670330

THIAW, I. 2003. Archaeology and the public in Senegal: reflections on doing fieldwork at home. Journal of African Archaeology 1: 27-35. http://dx.doi.org/10.3213/1612-1651-100010

Thomas, J. 2004. Archaeology and Modernity. London: Routledge.

TOMASKOVA, S. 2003. Nationalism, local histories and the making of data in archaeology. The Journal of the Royal Anthropological Institute 9: 485-507. http://dx.doi.org/10.1111/1467-9655.00160

Wiredu, K. 2005. A companion to African philosophy. Oxford: Blackwell. 